\title{
PENGARUH MODEL PEMBELAJARAN KOOPERATIF TIPE MAKE A MATCH TERHADAP HASIL BELAJAR SISWA PADA MATERI STRUKTUR ATOM KELAS X MIA SMA WAHIDIYAH KEDIRI
}

\author{
The Effect Of Cooperative Learning Model Make A Match Type On Student \\ Learning Outcomes In The Atom Structure Material in Class X Mia of Senior \\ High School of Wahidiyah Kediri
}

\author{
Jami' Lamhatil Ma'rifah, Mawadatur Rohmah, Firmansyah \\ Program Studi Pendidikan Kimia Fakultas Keguruan dan Ilmu Pendidikan \\ Universitas Wahidiyah Kediri, Jawa Timur \\ Email: fugen.lbb@gmail.com
}

\begin{abstract}
Abstrak. Penelitian ini bertujuan untuk mengetahui pengaruh yang signifikan dari penggunaan model pembelajaran kooperattif tipe make a match terhadap hasil belajar siswa. Siswa dibagi kedalam kelompok kecil untuk mencari pasangan kartu yang dipegang. Metode dalam penelitian ini adalah penelitian quasi eksperimen dengan desain penelitian pre-test dan post-test. Penelitian ini dilakukan di SMA Wahidiyah Kediri kelas X MIA semester ganjil tahun ajaran 2019/2020 pada materi struktur atom. Sampel yang diambil penelitian ini adalah kelas X MIA 1 sebagai kelas kontrol dan X MIA 2 sebagai kelas eksperimen. Teknik pengambilan data berupa soal tes yakni untuk pre-test dan post-test. Teknik analisis data dilakukan dengan uji-t. Hasil uji-t diperoleh nilai signifikasi $0,000<0,05$ yang menunjukkan terdapat pengaruh terhadap hasil belajar siswa pada penggunaan model pembelajaran kooperatif tipe make a match. Rata-rata skor hasil belajar siswa pada kelas eksperimen lebih tinggi daripada kelas kontrol yang menunjukkan bahwa model pembelajaran kooperattif tipe make a match efektif diajarkan kepada siswa.
\end{abstract}

Kata kunci: hasil belajar, make a match, struktur atom

\begin{abstract}
This study aims to determine the significant effect of the use of make a match cooperative learning models to student learning outcomes. Students are divided into small groups to find the pairs of cards they hold. The method in this study is a quasi-experimental study with a pre-test and post-test research design. This research was conducted in class X MIA of Senior High School of Wahidiyah Kediri at the odd semester of academic year 2019/2020 on atomic structure material. The sample taken in this study were class X MIA 1 as a control class and $\mathrm{X}$ MIA 2 as an experimental class. Data collection techniques in the form of test questions, namely for pre-test and post-test. Data analysis technique is done by ttest. T-test results obtained significance value of $0,000<0.05$ which indicates there is an influence on student learning outcomes on the use of make a match type of cooperative learning model. The average score of student learning outcomes in the experimental class is higher than the control class which shows that the make a match cooperative learning model is effectively taught to students.
\end{abstract}

Keywords: learning outcomes, make a match, atomic structure 


\section{PENDAHULUAN}

Berkembangnya keterampilan abad 21 tidak lepas dari berkembangnnya suatu pengetahuan karena pengetahuan adalah dasar yang menjadi landasan pola berpikir kearah kemajuan. Kemajuan suatu bangsa ditentukan dari semangat siswa dalam mengenyam dunia pendidikan. Di dalam pendidikan terdapat perubahan pola pikir siswa kearah perubahan yang lebih positif karena siswa dilibatkan secara aktif dalam proses belajar (Fitri, 2012).

Pendidikan merupakan aspek yang paling penting dalam menunjang kemajuan bangsa dimasa depan, karena melalui pendidikan manusia dapat mengembangkan potensi-potensi yang ada dalam dirinya, baik itu potensi rohani maupun jasmani (Syah,2010). Salah satu langkah mewujudkan pendidikan yang unggul dapat melalui lembaga pendidikan yaitu sekolah. Di sekolah siswa akan melakukan kegiatan belajar mengajar. Belajar adalah proses perubahan perilaku yang relatif menetap sebagai hasil dari pengalaman. Belajar merupakan proses yang dilakukan manusia sepanjang hidup untuk menambah wawasan-wawasan baru. Belajar merupakan proses manusia mencapai berbagai macam kompetensi, keterampilan, dan sikap (Baharuddin, 2015). Siswa dapat dikatakan belajar dengan baik jika siswa tersebut dapat mempelajari apa yang seharusnya dipelajari, sehingga tujuan pembelajaran yang diinginkan dapat dicapai oleh siswa.

Kurikulum 2013 lebih mengedepankan peran siswa dalam pembelajaran. Guru bertugas sebagai fasilisator, sehingga dalam aplikasinya, pembelajaran yang berpusat pada siswa dapat menumbuhkan interaksi antara guru dengan siswa ataupun sebaliknya. Konsep tersebut sejalan dengan pendidikan interaksional. Pendidikan interaksional lebih menekankan interaksi dua pihak, dari guru kepada siswa dan dari siswa kepada guru (Slameto, 2013). Lebih luas, interaksi tersebut juga terjadi antara siswa dengan bahan ajar dan dengan lingkungan, antara pemikiran siswa dengan kehidupannya.

Saat pembelajaran di kelas siswa dituntut aktif dalam pembelajaran, oleh karena itu kita dapat menggunakan model-model pembelajaran kooperatif. Model pembelajaran kooperatif dikembangkan untuk mencapai hasil belajar berupa prestasi akademik, toleransi, menerima keragaman, dan pengembangan keterampilan sosial. Pembelajaran kooperatif merupakan bentuk pembelajaran dengan cara siswa belajar dan bekerjasama dalam kelompok-kelompok kecil secara kolaboratif yang anggotanya terdiri dari empat sampai enam orang dengan struktur kelompok yang heterogen (Rusman, 2010). Pembelajaran kooperatif terkadang disebut juga kelompok pembelajaran. Pada umumnya dalam implementasi model pembelajaran kooperatif, para siswa saling berbagi, bertukar pikiran tentang hal-hal sebagai berikut : (1) siswa bekerjasama tentang suatu tugas bersama, atau kegiatan pembelajaran yang akan tertangani, (2) siswa bekerjasama dalam suatu kelompok kecil yang terdiri dari 2-6 orang, (3) siswa bekerjasama, berperilaku pro-sosial untuk menyelesaikan tugas bersama atau kegiatan pembelajaran, (4) siswa saling bergantung secara positif, (5) setiap siswa bertanggungjawab secara individu terhadap tugas yang menjadi bagiannya. Oleh sebab itu, para siswa sebaiknya perlu diberi kesempatan untuk berinteraksi dengan temantemannya agar mereka dapat memperoleh kemampuan yang lebih luas tentang dunia dan menemukan cara-cara baru untuk mengekspresikan gagasan dan perasaannya (Huda, 2011). Pembelajaran kooperatif diharapkan mampu meningkatkan kualitas pembelajaran 
di dalam kelas. Salah satu model pembelajaran kooperatif adalah model make a match (mencari pasangan) dengan materi struktur atom.

Model pembelajaran kooperatif tipe make a match memiliki karakteristik siswa gemar bermain. Model pembelajaran make a match dikembangkan pertama kali pada 1994 oleh Curren (Huda, 2013). Pembelajaran kooperatif tipe make a match merupakan pembelajaran dengan membagi siswa kedalam kelompok kecil yang mencari pasangan. Pembelajaran ini termasuk pembelajaran aktif dan merupakan salah satu teknik intruksional dari berfikir aktif yang dapat membantu siswa dalam hal mengingat apa yang telah mereka pelajari dan dapat menguji pemahaman siswa setelah guru menjelaskan materi pembelajaran. Keunggulan tipe make a match adalah siswa mencari pasangan kartu yang mereka bawa sambil belajar mengenai materi pelajaran tersebut dalam suasana yang menyenangkan serta dapat membuat siswa termotivasi sehingga menjadi aktif untuk mencari pasangan kartu mereka. Teknik ini biasa digunakan dalam semua mata pelajaran dan untuk semua tingkatan usia (Isjoni, 2010).

Penggunaan model make a match akan menumbuhkan interaksi antara siswa dengan siswa ataupun siswa dengan lingkungan dapat diciptakan melalui proses kerjasama. Kerjasama merupakan salah satu nilai yang perlu ditanamkan kepada siswa. Nilai tersebut dapat muncul jika diterapkan model pembelajaran kooperatif, sebab dalam pembelajaran kooperatif akan terjadi kerjasama antar siswa (Johnson, 2011). Meskipun kerjasama menghasilkan nilai yang baik ada beberapa guru yang tidak ingin menggunakan sistem kerjasama. Alasan para guru enggan menerapkan sistem kerjasama yaitu kekhawatiran akan terjadi kekacauan didalam kelas dan siswa tidak belajar jika mereka ditempatkan dalam grup (Anita,2000). Selain itu, orang-orang mempunyai kesan negatif mengenai kegiatan kerjasama atau belajar dalam kelompok.

Berdasarkan hasil wawancara yang dilakukan peneliti dengan siswa kelas X MIA di SMA Wahidiyah Kediri tahun ajaran 2018/2019 pada tanggal 30 April 2019, diperoleh informasi bahwa siswa banyak yang tidak terlalu suka dengan kimia dikarenakan pelajaran kimia itu membosankan, rumit, sulit dan banyak rumus yang dihafal sehingga membuat siswa jenuh. Siswa menganggap bahwa kimia tidak ada penerapannya dalam kehidupan sehari-hari. Siswa kesulitan dalam pelajaran kimia salah satunya pada materi struktur atom. Siswa merasa kesusahan dalam memahami materi struktur atom. Siswa masih kurang jelas dengan materi yang disampaikan oleh guru yang masih menggunakan metode ceramah dalam meyampaikan materi. Guru terlalu fokus pada materi yang disampaikan sehingga kurang memperhatikan siswanya, sehingga siswa ada yang tidur dan bicara sendiri.

Make a match merupakan salah satu jenis dari model dalam pelajaran kooperatif. Make a match adalah model pembelajaran yang dapat digunakan dalam pembelajaran kimia pada materi struktur atom. Model make a match sebagai media pembelajaran merupakan media yang dapat membuat siswa aktif dan dapat menumbuhkan rasa ingin tahu siswa terhadap materi yang akan dipelajari sehingga diperoleh hasil belajar yang memuaskan. Hasil belajar siswa dapat meningkat karena model make a match merupakan salah satu model pembelajaran yang dengan teknik siswa mencari pasangan sambil belajar mengenai suatu konsep atau topik, dalam suasana yang menyenangkan (Samani et al., 2012). Sehingga, berdasarkan permasalahan diatas penulis tertarik untuk melakukan penelitian tentang "Pengaruh Model Pembelajaran Kooperatif Tipe Make A 
Match Terhadap Hasil Belajar Siswa pada Materi Struktur Atom Kelas X MIA SMA Wahidiyah Kediri”.

\section{METODE PENELITIAN}

Penelitian ini merupakan penelitian eksperimen semu (quasi eksperimen) dengan menggunakan rancangan pra-tes dan pasca-tes. Rancangan ini bertujuan untuk mengungkapkan bagaimana pengaruh hasil belajar siswa yang dibelajarkan dengan model make a match dan dibelajarkan dengan metode konvensional (ceramah). Rancangan tersebut menggunakan kerjasama kelompok, dimana setiap siswa mendapat sebuah kartu soal ataupun jawaban, lalu secepatnya mencari pasangan yang sesuai dengan kartu yang ia pegang. Rancangan penelitian dapat dilihat pada tabel 1.

Tabel 1. Rancangan Penelitian

\begin{tabular}{cccc}
\hline Rancangan & Pra-tes & Perlakuan & Pasca-tes \\
$\mathrm{R}_{1}$ & $\mathrm{O}_{1}$ & $\mathrm{X}_{1}$ & $\mathrm{O}_{3}$ \\
$\mathrm{R}_{2}$ & $\mathrm{O}_{2}$ & - & $\mathrm{O}_{4}$ \\
\hline
\end{tabular}

Keterangan:

$\mathrm{R}_{1} \quad$ : kelompok eksperimen

$\mathrm{R}_{2} \quad$ : kelompok kontrol

$\mathrm{O}_{1} \quad$ : tes awal pada kelompok eksperimen

$\mathrm{O}_{2} \quad$ : tes awal pada kelompok kontrol

$\mathrm{X}_{1}$ : pembelajaran dengan menggunakan media pembelajaran kartu domino

$\mathrm{O}_{3} \quad$ : tes hasil belajar setelah perlakuan pada kelompok eksperimen

$\mathrm{O}_{4} \quad$ : tes hasil belajar setelah perlakuan pada kelompok kontrol

Variabel yang digunakan berupa variabel terikat, variabel bebas, dan variabel kontrol. Variabel bebas dalam penelitian ini adalah pembelajaran dengan menggunakan kerjasama siswa menggunakan model pembelajaran make a match pada kelompok kontrol. Variabel terikat dalam penelitian ini adalah hasil belajar siswa. Sedangkan variabel kontrol dalam penelitian ini adalah guru, jam pelajaran, instrumen penilaian, dan kurikulum yang sama. Penelitian ini dilakukan pada bulan April sampai dengan Juli tahun 2019, tahun pelajaran 2019/2020. Adapun lokasi dilakukannya penelitian ini adalah di SMA Wahidiyah Kediri yang beralamat Jl. KH Wahid Hasyim Bandar Lor Kec. Mojoroto kota Kediri Jawa Timur.

Populasi adalah wilayah generalisasi yang terdiri atas objek/subjek yang mempunyai kualitas dan karakteristik tertentu yang ditetapkan oleh peneliti untuk dipelajari dan kemudian ditarik kesimpulan (Sugiyono, 2016). Populasi dalam penelitian ini adalah siswa kelas X MIA SMA Wahidiyah Kediri. Sampel adalah sebagian atau wakil populasi yang diteliti (Arikunto, 2009). Sampel dalam penelitian ini adalah siswa kelas X MIA 1 dan X MIA 2 SMA Wahidiyah Kediri tahun pelajaran 2019/2020. Kelas X MIA 1 sebagai kelas kontrol dan kelas X MIA 2 sebagai kelas eksperimen.

Data yang dikumpulkan adalah hasil wawancara dan data hasil belajar siswa yang diperoleh melalui pre-tes dan post-tes. Tes hasil belajar yang digunakan berbentuk pilihan ganda (multiple choise) yaitu untuk pretest berjumlah 20 butir soal dan post-test berjumlah 20 butir soal yang berkaitan dengan materi. Sebelum digunakan instrumen 
soal diuji validitas, reliabilitas, tingkat kesukaran butir soal, daya daya beda butir soal (Sukamdinata, 2010).

Analisis data merupakan pengolahan data dari hasil pengumpulan data (Arikunto, 2006). Analisis data bertujuan untuk menguraikan keterangan-keterangan atau data-data yang diproses agar data tersebut dapat dipahami oleh peneliti dan juga orang lain yang ingin mengetahui hasil penelitian. Analisis data yang digunakan adalah uji-t. Uji-t adalah salah satu uji yang digunakan untuk mengetahui ada atau tidak adanya perbedaan antara dua buah data. Uji-t pada penelitian ini digunakan pada uji kesamaan dua rata-rata untuk melihat kemampuan awal siswa dan uji hipotesis untuk melihat pengaruh penggunaan model pembelajaran koperatif tipe make a match. Sebelum dilakukan uji-t terlebih dahulu dilakukan uji prasyarat analisis berupa uji normalitas dan homogenitas. Uji normalitas dan uji homogenitas yang telah dilakukan sebelumnya digunakan untuk menentukan jenis uji hipotesis yang akan digunakan. Uji hipotesis parametrik yaitu uji-t, digunakan bila data yang diperoleh terdistribusi normal dan homogen. Bila data yang diperoleh tidak terdistribusi secara normal dan tidak homogen maka dilakukan uji hipotesis nonparametrik yaitu Mann-Whitney.

Untuk menguji hipotesis digunakan independent sample t-test dengan program SPSS versi 18 yang memiliki ketentuan yakni jika nilai sig (2-tailed) $<0,05$ maka kesimpulannya Ho ditolak dan Ha diterima. Tetapi jika nilai sig (2-tailed) > 0,05 maka kesimpulannya Ho diterima dan Ha ditolak. (Ha) adalah terdapat pengaruh yang signifikan menggunakan model kooperatif tipe make a match terhadap hasil belajar siswa. $\left(\mathrm{H}_{0}\right)$ adalah tidak terdapat pengaruh yang signifikan menggunakan model kooperatif tipe make a match terhadap hasil belajar siswa.

\section{HASIL DAN PEMBAHASAN}

Kelas kontrol pembelajarannya menggunakan motode konvensional (ceramah) sedangkan kelas eksperimen menggunakan model pembelajaran kooperatif tipe make a match. Deskripsi data nilai siswa dapat dilihat pada tabel berikut:

Tabel 2. Deskripsi Penilaian Terhadap Pre-Test dan Post-Test

\begin{tabular}{clcccc}
\hline No & \multicolumn{1}{c}{ Statistik } & \multicolumn{2}{c}{ Kelas Eksperimen } & \multicolumn{2}{c}{ Kelas Kontrol } \\
& & Pre-test & Post-test & Pre-test & Post-test \\
1 & Banyak siswa & 40 & 40 & 40 & 40 \\
2 & Skor Terendah & 30 & 65 & 20 & 60 \\
3 & Skor Tertinggi & 65 & 90 & 70 & 85 \\
4 & Mean (rata-rata) & 43,88 & 79,75 & 40,88 & 74,50 \\
5 & Std. Deviation & 9,573 & 6,597 & 12,594 & 6,076 \\
\hline
\end{tabular}

Berdasarkan tabel diatas diketahui terdapat perbedaan nilai pada skor pre-test dan post-test di kelas eksperimen dan kelas kontrol. Kelompok siswa yang mendapat perlakuan dengan model pembelajaran kooperatif tipe make a match memiliki skor ratarata lebih tinggi dibanding dengan kelompok siswa yang dalam pembelajarannya tidak menggunakan model pembelajaran kooperatif tipe make a match. Hasil tersebut dapat dilihat pada skor rata-rata penilaian post-test pada kedua kelas, kelas eksperimen mendapat skor nilai rata-rata 79,75 sedangkan kelas kontrol mendapat skor nilai ratarata 74,50. Selain itu skor post test tertinggi siswa pada kelas eksperimen lebih bagus dibandingkan skor post test tertinggi siswa pada kelas kontrol. Pada kelas eksperimen 
skor post test tertingi yaitu 90 sedangkan pada kelas kontrol yaitu 85. Sedangkan skor post test terendah siswa pada kelas eksperimen juga lebih bagus dibandingkan skor post test terendah siswa pada kelas kontrol. Pada kelas eksperimen skor post test terendah yaitu 65 sedangkan pada kelas kontrol yaitu 60 .

Sebelum dilakukan uji-t terhadap kemampuan awal siswa dan uji hipotesis penelitian, terlebih dahulu dilakukan uji prasyarat analisis berupa uji normalitas dan homogenitas. Uji normalitas bertujuan untuk menguji apakah semua data variabel berdistribusi normal atau tidak. Uji normalitas menggunakan rumus kolmogrov-smirnov, dalam perhitungannya menggunakan program SPSS versi 18 . Untuk mengetahui normal tidaknya adalah jika sig. $>0,05$ maka data terdistribusi normal dan jika sig. $<0,05$ maka dapat dikatakan data tidak terdistribusi normal. Hasil perhitungan yang diperoleh sebagai berikut:

Tabel 3. Hasil Uji Normalitas

\begin{tabular}{llcc}
\hline No & Kelompok & Signifikansi (2-tailed) & kesimpulan \\
1 & Pre-test & 0,84 & Normal \\
2 & Post-test & 0,53 & Normal \\
\hline
\end{tabular}

Berdasarkan hasil uji normalitas dengan uji kolmogrov-smirnov test menggunakan SPSS tipe $18 \mathrm{di}$ atas terlihat bahwa data pre-test dan post-test terdistribusi normal dan memenuhi prasyarat analisis.

Selain melakukan uji normalitas juga dilakukan uji homogenitas. Uji homogenitas digunakan untuk mengetahui apakah data yang diperoleh dari kedua kelompok memiliki varian yang sama (homogen) atau tidak. Untuk mengetahui homogen tidaknya adalah jika sig. > 0,05 maka kedua kelompok memiliki varian yang sama (homogen) dan jika sig. < 0,05 maka dapat dikatakan kedua kelompok tidak homogen. Hasil uji homogenitas sebagai berikut:

Tabel 4. Hasil Uji Homogenitas

\begin{tabular}{ccc}
\hline Variabel & Signifikansi (2-tailed) & Keterangan \\
Pre-test & 0,069 & Homogen \\
Pre-test & 0,62 & Homogen \\
\hline
\end{tabular}

Berdasarkan hasil uji homogenitas dengan uji one a way anova menggunakan SPSS tipe 18 di atas terlihat bahwa data pre-test dan post-test memiliki varian yang sama (homogen). Hal ini dikarenakan nilai signifikasi > 0,05, dengan nilai 0,069 untuk pretest dan 0,62 untuk post-test. Dengan demikian, maka data yang sedang diteliti mempunyai kesamaan atau sama lain.

Data penelitian menunjukkan kedua kelas tersebut terdistribusi normal dan memiliki varian yang sama (homogen). Selanjutnya dilakukan uji kesamaan dua rata-rata (kemampuan awal siswa) menggunakan uji independent t-test. Uji kesamaan dua ratarata (kemampuan awal siswa) menggunakan nilai pre-test siswa. Adapun hasil uji independent $t$-test kemampuan awal siswa dapat dilihat pada tabel berikut:

Tabel 5.Uji Kemampuan Awal (pre-test)

\begin{tabular}{lccc}
\hline \multicolumn{1}{c}{ Pre-test } & $\mathrm{t}$ & $\mathrm{Df}$ & Signifikansi (2-tailed) \\
Kelas eksperimen & 78 & 78 &, 242 \\
Kelas kontrol & 78 & 71,813 &, 242 \\
\hline
\end{tabular}


Pada tabel 5 di atas, terlihat bahwa nilai signifikansi adalah 0,242. Nilai signifikansi tersebut lebih dari 0,05 , maka $\mathrm{H}_{0}$ diterima atau dapat dinyatakan bahwa kemampuan awal siswa pada kelas eksperimen dan kontrol tidak berbeda secara signifikan. Siswa pada kelas kontrol dan eksperimen memiliki kemampuan awal yang sama.

Selanjutnya dilakukan uji kemampuan akhir untuk menguji hipotesis penelitian. Data yang digunakan dalam uji hipotesis penelitian adalah nilai post tes siswa. Hipotesis penelitian menyatakan: Haberarti terdapat pengaruh yang signifikan menggunakan model kooperatif tipe make a match terhadap hasil belajar siswa dan $\mathrm{H}_{0}$ berarti tidak terdapat pengaruh yang signifikan menggunakan model kooperatif tipe make a match terhadap hasil belajar siswa. Adapun hasil uji independent t-test hipotesis penelitian dapat dilihat pada tabel berikut:

Tabel 6. Uji Kemampuan Akhir (post-test)

\begin{tabular}{cccc}
\hline Post-test & T & Df & Signifikansi (2-tailed) \\
Kelas eksperimen & 3,702 & 78 &, 000 \\
Kelas kontrol & 3,702 & 77,478 &, 000 \\
\hline
\end{tabular}

Berdasarkan hasil uji independen t-test menggunakan SPSS tipe 18 di atas terlihat bahwa taraf signifikasi < 0,05, sehingga disimpulkan bahwa $\mathrm{H}_{0}$ ditolak dan $\mathrm{Ha}$ diterima. Hal ini menunjukkan bahwa ada pengaruh yang signifikan terhadap hasil belajar siswa pada penggunaan model pembelajaran kooperatif tipe make a match. Ratarata skor hasil belajar siswa pada kelas eksperimen lebih tinggi daripada kelas kontrol yang menunjukkan bahwa model pembelajaran kooperattif tipe make a match efektif diajarkan kepada siswa. Hal ini dikarenakan model pembelajaran kooperatif tipe make a match mengutamakan kerja sama dalam pembelajaran. Pentingnya kerjasama dalam kelompok yaitu untuk mencapai hasil yang maksimal dalam pembelajaran (Sudjana, 2009). Kelompok kerja adalah mitra dalam bekerja untuk mencapai hasil belajar yang maksimal sehingga materi yang diberikan dapat diterima dengan baik. Pada prosesnya peneliti membagi siswa menjadi 8 kelompok dan setiap kelompok terdiri dari 5 orang. Adanya kelompok kecil mengakibatkan sosialisasi dalam pembelajaran semakin cepat sehingga hasil yang diinginkan juga mudah untuk dicapai dibandingkan dengan kerja mandiri. Disinilah terlihat bahwa model pembelajaran kooperatif tipe make a match dapat mengembangkan kerjasama siswa (Khairini, 2017). Kerjasama siswa yang terjalin dengan baik akan membuat tujuan pembelajaran dapat tercapai dan hasil belajar meningkat. Teknik ini dapat juga digunakan dalam semua mata pelajaran dan untuk semua tingkatan usia anak didik (Shoimin, 2017).

Kerjasama merupakan hal yang penting bagi kehidupan manusia, karena dengan kerjasama manusia dapat melangsungkan kehidupannya. Kerjasama juga menuntut interaksi antara beberapa pihak. Kerjasama dapat menghilangkan hambatan mental akibat terbatasnya pengalaman dan cara pandang yang sempit, sehingga akan mungkin untuk menemukan kekuatan dan kelemahan diri, belajar menghargai orang lain, mendengarkan dengan pikiran terbuka, dan membangun persetujuan bersama (Johnson, 2011). Kerjasama dalam konteks pembelajaran yang melibatkan siswa. Ketika siswa bekerja sama untuk menyelesaikan suatu tugas kelompok, mereka memberikan dorongan, anjuran, dan informasi pada teman sekelompoknya yang membutuhkan 
bantuan. Hal ini berarti dalam kerjasama, siswa yang lebih paham akan memiliki kesadaran untuk menjelaskan kepada teman yang belum paham (Huda, 2011).

Model make a match sebagai media pembelajaran merupakan media yang dapat membuat siswa aktif dan dapat menumbuhkan rasa ingin tahu siswa terhadap materi yang akan dipelajari sehingga diperoleh hasil belajar yang memuaskan (Suprijono, 2009). Hasil belajar siswa dapat meningkat karena model make a match merupakan salah satu model pembelajaran dimana siswa mencari pasangan sambil belajar mengenai suatu konsep atau topik, dalam suasana yang menyenangkan. Penggunaan model make a match dalam kelas yaitu guru menyiapkan beberapa pertanyaan dengan materi yang dipelajari yang ditulis dalam kartu pertanyaan. Guru membuat jawaban dari pertanyaan yang telah dibuat dan dituliskan pada kartu jawaban. Kartu jawaban ditulis di kartu yang berbeda warna. Siswa dibagi dalam kelompok, setiap kelompok menerima kartu soal/kartu jawaban. Siswa mencari pasangan kartu yang cocok dengan kartu yang dimiliki. Model pemebelajaran kooperatif make a match ini dapat meningkatkan nilai kerjasama siswa dan hasil belajar siswa dikarenakan beberapa hal yaitu (Widoyoko, 2010): (1) mampu menciptakan suasana aktif dan menyenangkan; (2) materi pembelajaran yang disampaikan lebih menarik perhatian siswa; (3) mampu meningkatkan hasil belajar siswadan mencapai taraf ketuntasan belajar; (4) suasana kegembiraan akan tumbuh dalam proses pembelajaran; (5) kerjasama antar siswa terwujud dengan dinamis; dan (6) munculnya dinamika gotong royong yang merata diseluruh siswa.

\section{SIMPULAN}

Hasil uji-t terhadap nilai post test siswa diperoleh nilai signifikasi $0,000<0,05$ yang menunjukkan terdapat pengaruh signifikan terhadap hasil belajar siswa pada penggunaan model pembelajaran kooperatif tipe make a match. Rata-rata skor hasil belajar siswa pada kelas eksperimen lebih tinggi daripada kelas kontrol yang menunjukkan bahwa model pembelajaran kooperattif tipe make a match efektif diajarkan kepada siswa. Sehingga disarankan kepada pengajar untuk menggunakan model kooperatif tipe make a match sebagai alternatif didalam pembelajaran untuk meningkatkan hasil belajar siswa namun juga perlu disesuaikan juga dengan keadaan siswa.

\section{DAFTAR RUJUKAN}

Anita, L. (2000). Cooperatif Learning. Jakarta: Grafindo.

Arikunto, S. 2009. Prosedur Penelitian Suatu pendidikan Praktik. Edisi Revisi 6. Jakarta: Rineka Cipta.

Baharuddin \& Wahyu, E. (2015). Teori belajar dan pembelajaran. Yogyakarta. Ar-Ruzz Media.

Fitri, Agus Zaenal. (2012). Pendidikan karakter berbasis nilai \& etika di sekolah. Yogyakarta: Ar-Ruzz Media.

Huda, M. (2011). Cooperative Learning. Yogyakarta: Pustaka Belajar.

Huda, M. (2013). Model-model Pengajaran dan Pembelajaran. Yogyakarta: Pustaka Belajar. 
Dalton : Jurnal Pendidikan Kimia dan Ilmu Kimia, Volume 3 Nomor 1, Mei 2020

Isjoni. (2010). Pembelajaran kooperatif meningkatkan kecerdasan komunikasi antara peserta didik. Yogyakarta: Pustaka Pelajar

Isjoni. (2011). Pembelajaran Kooperatif. Yogyakarta: Pustaka Pelajar.

Johnson, E. (2011). Contextual Teaching And Learning Menjadikan Kegiatan BelajarMengajar Mengasikkan dan Bermakna. Bandung: Kaifa Learning.

Khairini. (2017). Pengaruh Model Make A Match dan Gaya Kognitif Terhadap Hasil Belajar Siswa SMA Bina Bangsa Aceh Besar pada Materi Tata Nama Senyawa. Skripsi. Universitas Islam Negeri Ar-Raniry, Banda Aceh.

Rusman. (2010). Model-model Pembelajaran (Mengembangkan Profisionalisme Guru Edisi Kedua). Jakarta: Raja Grafindo Persada.

Samani, Muchlas, dan Haiyanto. (2012). Pendidikan Karakter. Bandung: PT Remaja Rosdakarya.

Shoimin, A. (2017). 68 model pembelajaran inovatif dalam kurikulum 2013. Yogyakarta: Ar-Ruzz Media.

Slameto. (2013). Belajar dan faktor-faktor yang mempengaruhi. Jakarta: PT Rineka.

Sudjana, N. (2009). Penilaian Hasil Proses Belajar Mengajar. Bandung: PT. Remaja Rosdakarya.

Sugiyono. (2016). Metode Penelitian Kuantitatif, Kuantitatif, dan R\&D. Bandung: CV Alfabeta.

Sukamdinata. (2010). Metode Penelitian Pendidikan. Bandung: PT Remaja Rosdkarya.

Suprijono, A. (2009). Cooperative Learning. Yogyakarta: Pustaka Pelajar.

Syah, M. (2010). Psikologi pendidikan dengan pendekatan baru. Bandung: PT Remaja Rosolakarya.

Widoyoko \& Eko, P. (2014). Penilaian Hasil Pembelajaran Di Sekolah. Yogyakarta: Pustaka Belajar. 